\title{
8 \\ The process of Sri Lankan migration to Australia focusing on irregular migrants seeking asylum
}

\section{Graeme Hugo and Lakshman Dissanayake}

\section{Introduction}

Sri Lanka is one of the contemporary world's major emigration nations. The United Nations (2013) has shown that there were 1.25 million Sri Lankan-born persons living outside of their country of birth, equivalent to 5.9 per cent of the current Sri Lankan resident population. Australia is one of the important destination countries, with an estimated 106,280 Sri Lankan-born residents in 2013 (Australian Bureau of Statistics, 2013). While Australia has only 7.9 per cent of the overseas Sri Lankan population, it is an important part of the Sri Lankan diaspora. Not only has the Sri Lankan presence in Australia been established for a long period (Weerasooria, 1988), but as well it comprises predominantly permanent settlers who have maintained important linkages with their homeland.

Sri Lankan immigrants are the 13th largest overseas-born group in Australia and their movement to Australia has a long history. It has become increasingly complex, with movement in both directions and increasing levels of both permanent and non-permanent migration. This complexity increased in 2012-13, with the sudden influx of over 6,000 Sri Lankan irregular maritime arrivals (IMAs) seeking asylum, and with 
the repatriation of significant numbers. This study adopts a multisite, mixed-method approach to analysing this mobility within the broader context of all Sri Lankan migration to Australia. By collecting, analysing and interpreting quantitative and qualitative information from origin, transit and destination countries, the study seeks to understand the nature and drivers of the process of irregular movement from Sri Lanka to Australia. It investigates the characteristics of the movers and the decision-making processes that underlie irregular migration, selecting a destination and whether or not to return. It examines how individual, family and contextual factors influence the migration as well as the role of social networks and the Sri Lankan diaspora. The findings are related to migration theory and their implications for understanding irregular migration more generally and Australian IMA policy are discussed.

\section{Methods and data}

In Sri Lanka, we collected existing research and secondary data sources and carried out key informant interviews with the Sri Lanka Police, Immigration and Emigration Officials and Criminal Investigation Department staff, since they deal directly with the Sri Lankan irregular maritime migrants who are captured at the Sri Lankan border, as well as with those who are sent back by the Australian authorities after disqualifying them for asylum status. The main secondary data sources that the current study used for its analysis are:

- the Sri Lanka Population Census 2012 (5 per cent sample);

- data from the Department of Immigration and Emigration;

- data from the Sri Lanka Bureau of Foreign Employment;

- airport statistics;

- data from the Criminal Investigation Department on IMAs;

- data from a few regional police stations; and

- data and information from various media reports.

In addition, two people smugglers, four facilitators and 17 IMAs were interviewed to gather information about the process of irregular migration to Australia. 
The Australian secondary data used here is of two types. The first is the quinquennial population census, which is a high quality total count of the population in each year that ends with a one or a six. Sri Lankans can be identified by their place of birth, their ancestry or the language they speak at home. Here, we mainly use the birthplace information. Extensive use is also made of data collected at the Australian borders about all persons arriving and departing.

\section{Sri Lanka-A quintessential emigration country}

Sri Lanka's geographical position has had a significant impact on population movement into and out of the country over the years. At the latest census of 2012, the total population of Sri Lanka was estimated to be $20,277,597$. Sri Lanka is a multiethnic country, comprising 75 per cent Sinhalese, 11 per cent Sri Lankan Tamils, 4 per cent Indian Tamils and 9 per cent Moors (and less than 1 per cent of various other ethnicities such as Burgher and Malays). The Sinhalese population is substantially distributed over the southern and western parts of Sri Lanka, while Muslims dominate the eastern region and most Sri Lankan Tamils live in the northern part of the island. A substantial proportion of Tamils live in the Colombo district, where the commercial capital is located.

The post-independence era has been significantly marked by the conflict between Sinhalese and Tamils, and these tensions still have an enormous impact on political and economic development as well as migration patterns in Sri Lanka. Sri Lanka experienced a series of sociopolitical disturbances over around 30 years, which reduced growth and discouraged investment, destroyed human and physical capital, redirected natural resources to non-productive uses, and caused a dramatic deterioration in the quality of life-not only in communities in the north and east, but across all communities on the entire island. Impacts of the 30-year war, which ended in 2009, loom large when considering contemporary events in Sri Lanka. This is also the case when examining the movement of IMAs to Australia, particularly as the majority came from the war-affected northern and eastern parts of the island. 
Sri Lanka is a significant emigration nation with the United Nations (2013) showing that the number of Sri Lankan-born living in other countries increased from 0.8 to 1.3 million between 2000 and 2013, the equivalent of roughly 5-6 per cent of the resident population. Figure 8.1 shows the distribution of these migrants. Jayasuriya and McAuliffe (2013, pp. 6-7) explain that migration outflows of Sri Lankans can be categorised into five groups:

- temporary workers (skilled, semi-skilled and unskilled)

- skilled settlers

- students

- asylum seekers

- tourists, including pilgrims to Nepal and India.

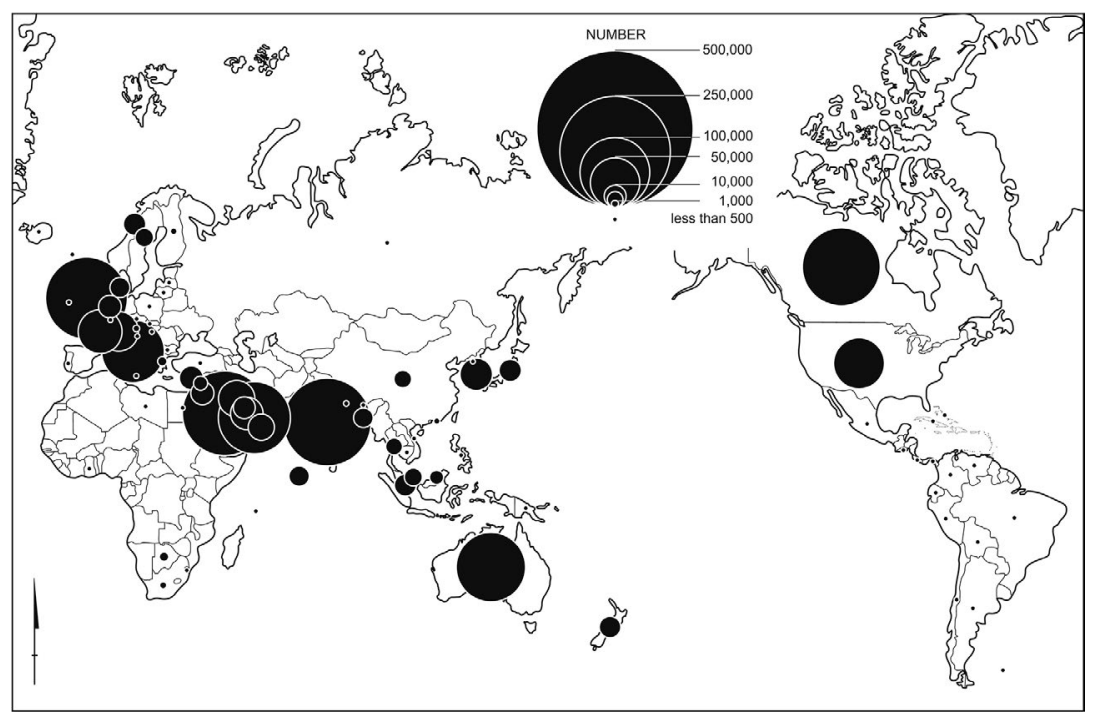

Figure 8.1: Countries of residence of the Sri Lankan diaspora, 2013 Source: United Nations (2013).

Since several of these flows are temporary or circular, not all are captured in United Nations' estimates of the numbers of Sri Lankan-born persons resident outside of Sri Lanka. Contract labour migration of low-skilled workers, especially female domestic workers to the Middle East and to a lesser extent Southeast and East Asia, has increased, as Figure 8.2 shows. 


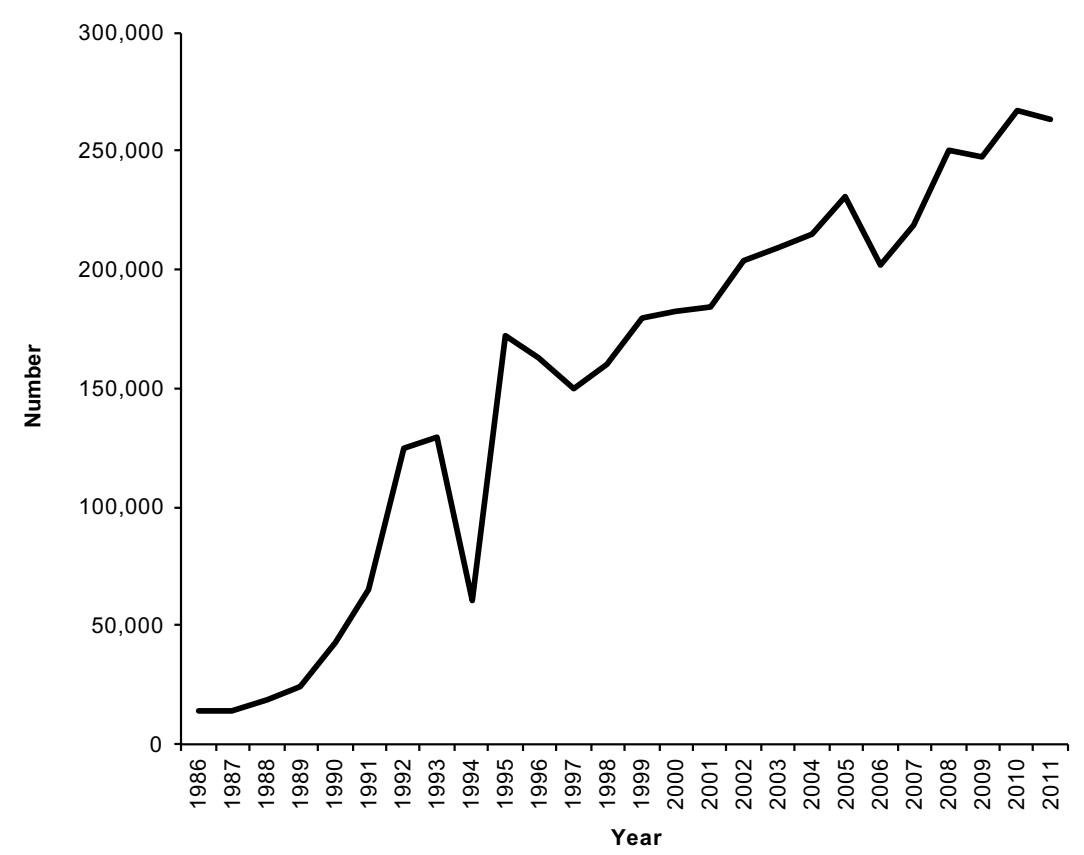

Figure 8.2: Sri Lanka: Departures for foreign employment, 1986-2011 Source: Sri Lanka Bureau of Foreign Employment.

Irregular migration has been an important element in Sri Lankan emigration for several decades. It is difficult to estimate the size of this outflow because it occurs outside of the formal migration system. There has also been an outflow of refugees and asylum seekers, mostly associated with civil conflict involving Tamils in the north and east of the country. India has been the main destination, but as Jayasuriya and McAuliffe (2013, p. 15) point out, people have also travelled within Sri Lanka, as well as to Australia, the UK, France, Switzerland, Canada, Germany, Japan and a number of other European, North American and Asian countries.

Links between Sri Lanka and its diaspora have become increasingly important. A major dimension of this has been the sending of remittances to Sri Lanka by expatriates overseas on a permanent or temporary basis. Remittances make up 10 per cent of the national gross domestic product (GDP). While the Middle East is the most important source of remittances, Australia is also a significant source. This reflects the fact that the Australian Sri Lankan community is a tightly knit one, maintaining 
strong links with the homeland (Weerasooria, 1988). It is important to note that there are also high levels of internal migration within Sri Lanka. At the 2012 population census, almost a fifth of Sri Lankans (19 per cent, or 3.86 million) were living in a district other than the one in which they were born.

There is some evidence in Sri Lanka of a strong link between internal migration and international migration (Hugo, 2015; King, Skeldon, \& Vullnetari, 2008). Internal migration, especially rural-urban movement, can be the first stage of a subsequent international migration (Cornelius, 1992; del Rey Poveda, 2007, pp. 291-92; King, 1976, pp. 70-72; Lozano-Ascencio, Roberts, \& Bean, 1999; Skeldon, 2006, pp. 22-24; Zabin \& Hughes, 1995). Nevertheless, direct migration from rural areas to international destinations also occurs in international labour migration flows (Cornelius, 1992, pp. 162-63; Lozano-Ascencio et al., 1999, p. 140; Zabin \& Hughes, 1995). Emigration may also be preceded by more than one internal move in multistep migration, perhaps starting from a small village, migrating to a provincial town and then on to the national capital before proceeding with an international move (Lozano-Ascencio et al., 1999). This suggests that it is imperative to study both the internal as well as international migration dynamics in order to understand the environment in which IMAs make decisions to migrate to Australia.

The effects of remittances and the obvious wealth of returning migrants has sent a strong signal to many Sri Lankans, especially young people, that migration offers an avenue to income-related success. The culture of migration is important to factor in any strategy addressing irregular migration to Australia.

\section{Sri Lankan migration to Australia}

There is a long history of migration from Sri Lanka to Australia extending over most of the period of European settlement. Table 8.1 summarises the major historical waves of Sri Lankan settlement migration to Australia. The Sri Lankan community in Australia is currently the sixth largest in the Sri Lankan diaspora, but Table 8.2 shows that it is only relatively recently that it has assumed a significant size. 
Table 8.1: Major historical trends in Sri Lankan migration to Australia

\begin{tabular}{|l|l|l|l|}
\hline Period & Description & $\begin{array}{l}\text { Ethnicity } \\
\text { of settlers }\end{array}$ & $\begin{array}{l}\text { Location } \\
\text { of settlement }\end{array}$ \\
\hline Up to 1870s & $\begin{array}{l}\text { Small-scale individual movement } \\
\text { between British colonies }\end{array}$ & Sinhalese & NSW, Victoria \\
\hline 1870 -1900 & $\begin{array}{l}\text { Flows of contract workers for sugar } \\
\text { plantations, permanent settlers }\end{array}$ & Sinhalese & $\begin{array}{l}\text { North Queensland, } \\
\text { NT, North Western } \\
\text { Australia }\end{array}$ \\
\hline 1870 -1900 & $\begin{array}{l}\text { Small-scale individual movement } \\
\text { to goldfields }\end{array}$ & Victoria, NSW \\
\hline $1900-50$ & Limited family migration & Sinhalese & Northern Australia \\
\hline $1950-80$ & $\begin{array}{l}\text { Migration of descendants of European } \\
\text { settlers, Colombo Plan students }\end{array}$ & Burghers & $\begin{array}{l}\text { Victoria, capital } \\
\text { cities }\end{array}$ \\
\hline $\begin{array}{l}\text { 1980s- } \\
\text { Present }\end{array}$ & Skilled and family migration, refugees & $\begin{array}{l}\text { Tamils, } \\
\text { Sinhalese }\end{array}$ & $\begin{array}{l}\text { Victoria, capital } \\
\text { cities }\end{array}$ \\
\hline $2012-13$ & Asylum seekers & Tamils & $\begin{array}{l}\text { Victoria (on } \\
\text { bridging visas) and } \\
\text { detention centres }\end{array}$ \\
\hline
\end{tabular}

Source: Authors' own research.

Table 8.2: Growth of the Sri Lankan-born population in Australia, 1901-2011

\begin{tabular}{|l|r|r|}
\hline Year & Population & \% Growth per annum \\
\hline 1901 & 609 & \\
\hline 1911 & 611 & 0.03 \\
\hline 1921 & 637 & 0.42 \\
\hline 1933 & 638 & 0.01 \\
\hline 1954 & 1,961 & 5.49 \\
\hline 1961 & 3,433 & 8.33 \\
\hline 1966 & 5,562 & 10.13 \\
\hline 1971 & 9,018 & 10.15 \\
\hline 1976 & 14,761 & 10.36 \\
\hline 1981 & 17,900 & 3.93 \\
\hline 1986 & 23,600 & 5.68 \\
\hline 1991 & 40,400 & 11.35 \\
\hline 1996 & 46,984 & 3.07 \\
\hline 2001 & 53,461 & 2.62 \\
\hline 2006 & 62,257 & 3.09 \\
\hline 2011 & 86,412 & 6.78 \\
\hline 2013 & 106,280 & 3.21 \\
\hline
\end{tabular}

Source: Data derived from Australian censuses, 1901 to 2011.

Note: The 1947 census population has been excluded because Sri Lanka and India were recorded together in that year. Growth between 2011 and 2013 is of the estimated resident population. 
The pattern of settlement migration since 1960 is shown in Figure 8.3 and it indicates that in the modern era there has been considerable annual variation in the flow of Sri Lankan permanent migrants to Australia. The final peak was in recent years and coincided with the end of the Civil War and an unprecedented increase in Australian skilled immigration associated with the mining boom (Hugo, 2014).

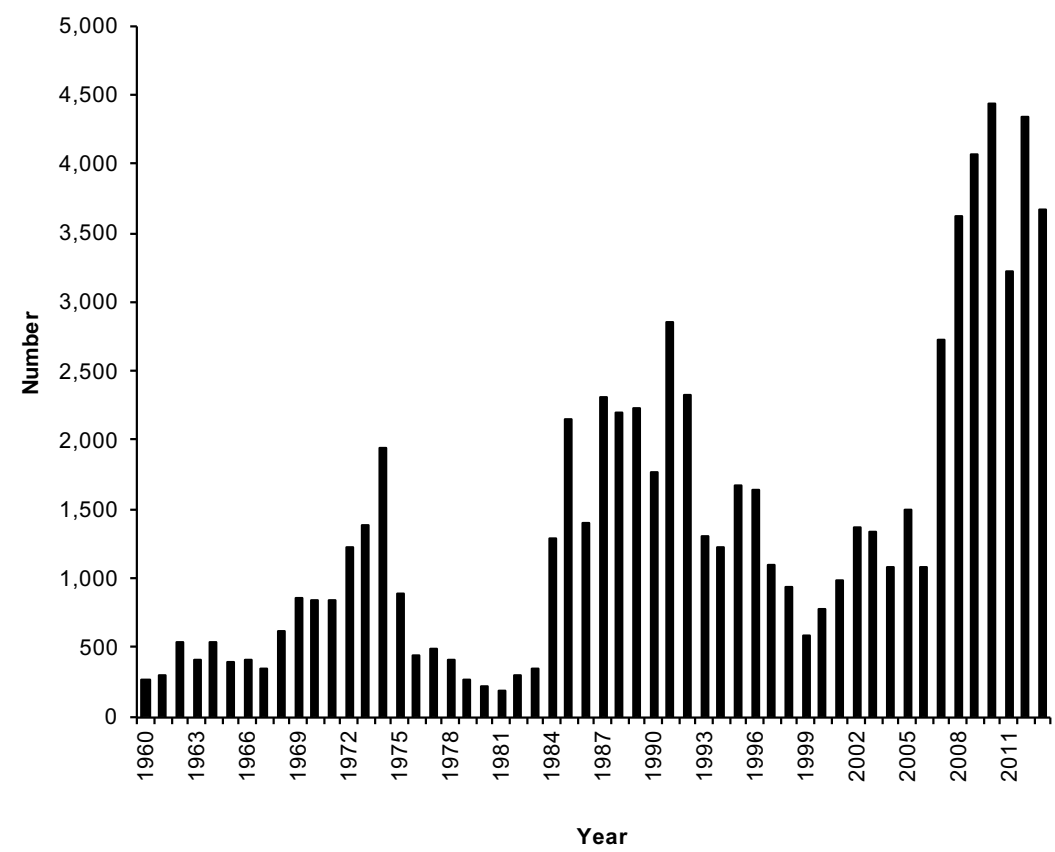

Figure 8.3: Settler arrivals from Sri Lanka to Australia, $1959-60$ to 2012-13

Source: Department of Immigration and Multicultural and Indigenous Affairs, Australian Immigration: Consolidated Statistics, various issues; Department of Immigration and Border Protection (DIBP), unpublished data.

Note: Settler arrivals from 2006-07 onwards are by country of birth.

One of the defining characteristics of permanent immigration to Australia since the mid-1990s has been the increasing focus of immigrant selection on skill and a reduction in family migration (Hugo, 1999). This has been the case in Sri Lankan immigration to Australia. Figure 8.4 shows how skilled migration has increasingly dominated Sri Lankan immigration in recent years. 


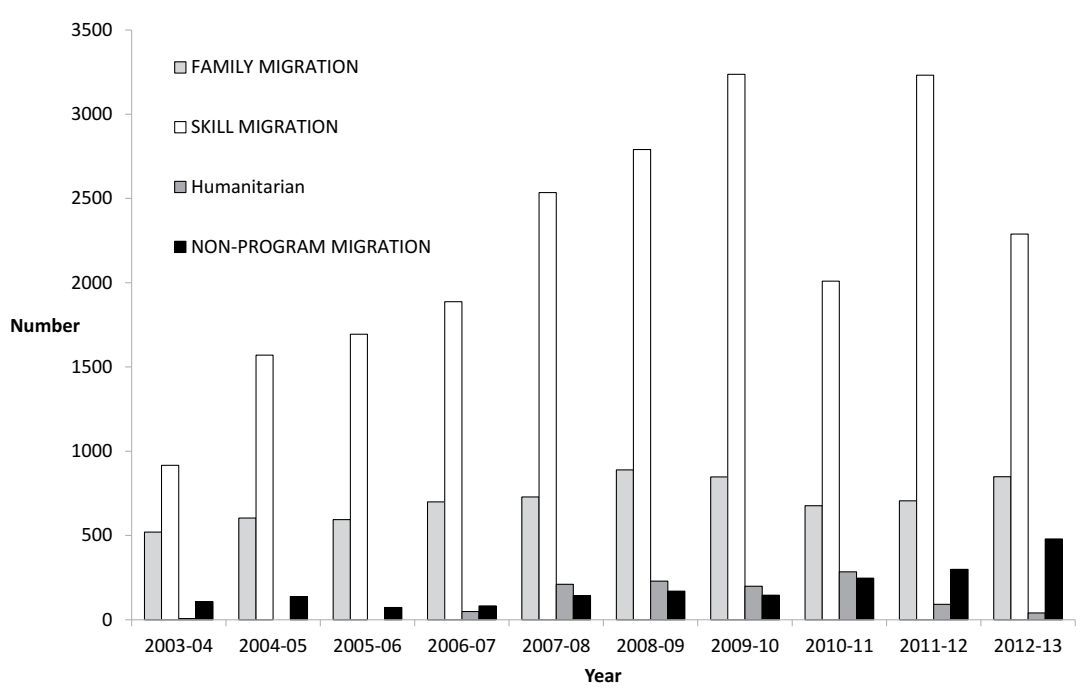

Figure 8.4: Australia: Sri Lankan-born by visa category, 2003-04 to 2012-13

Source: DIBP, unpublished data.

Particular attention in recent years has focused on asylum seeker and refugee migration to Australia from Sri Lanka. Figure $8.4^{1}$ shows that refugee migration has been a small but significant factor. In terms of refugee movement, Table 8.3 shows the numbers of refugees from Sri Lanka settled in Australia over the last decade or so, and the dominance of onshore settlers who arrived initially as asylum seekers.

Table 8.3: Australia: Humanitarian settlers from Sri Lanka

\begin{tabular}{|c|c|c|c|c|c|}
\hline Year & Onshore & Offshore & Year & Onshore & Offshore \\
\hline 2000-01 & 170 & 100 & 2007-08 & 370 & 210 \\
\hline 2001-02 & 115 & 55 & 2008-09 & 400 & 230 \\
\hline 2002-03 & 60 & 35 & 2009-10 & 505 & 200 \\
\hline 2003-04 & 25 & 5 & 2010-11 & 355 & 285 \\
\hline 2004-05 & 34 & & 2011-12 & 410 & 90 \\
\hline 2005-06 & 215 & & 2012-13 & 320 & 41 \\
\hline 2006-07 & 275 & 50 & & & \\
\hline
\end{tabular}

Source: DIBP, unpublished data.

1 Nonprogram migration arrivals consist mainly of New Zealand citizens arriving under the Trans-Tasman travel arrangement and a small group of other nonprogram arrivals (children born to Australian citizens overseas, residents of Cocos Islands, Norfolk Island and persons granted Australian citizenship overseas). 
The mid-1990s saw the introduction of a skilled temporary worker visa (subclass 457) (Khoo, McDonald, \& Hugo, 2009), as well as student and working holiday maker visas. This produced a paradigmatic shift in Australian migration (Hugo, 1999) and has reshaped Sri Lankan migration to Australia. Accordingly, Figure 8.5 shows how long-term arrivals $^{2}$ have a strikingly different pattern to the permanent migration flows in Figure 8.3. There has been a remarkably steep increase in the temporary immigrant inflow from Sri Lanka. It is clear that, to some extent, temporary migration is being used by some highly skilled Sri Lankans who hitherto would have used the permanent migration avenue to Australia. It has also led to new migrant flows.

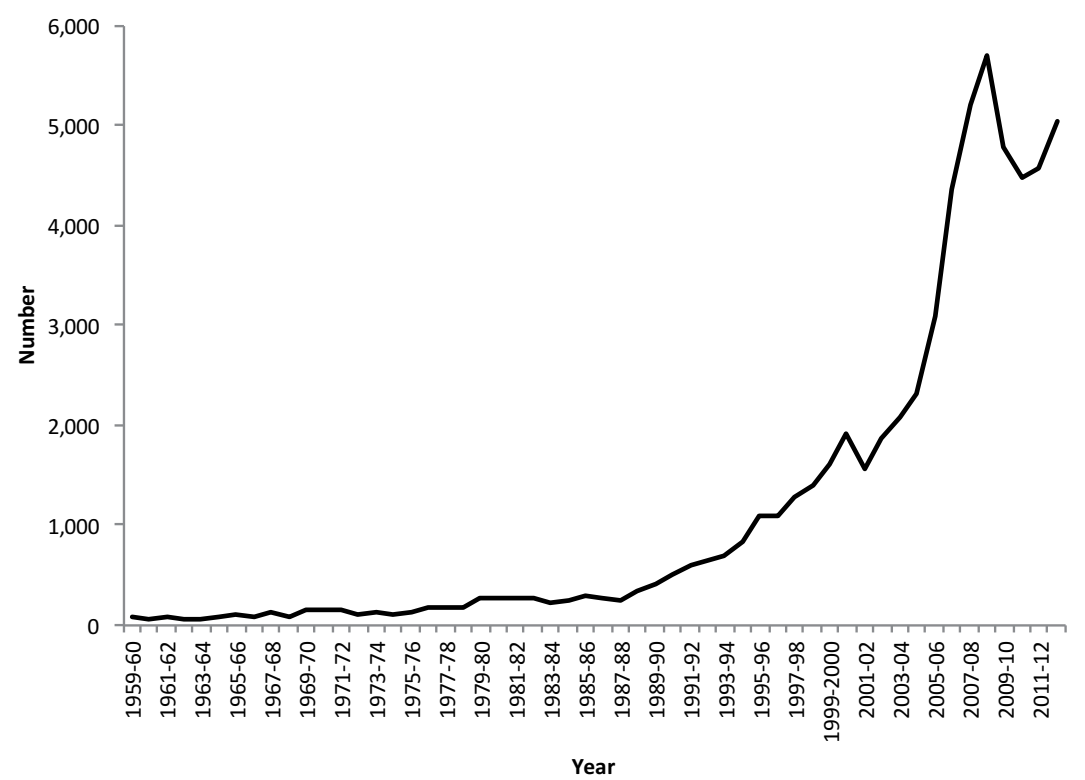

Figure 8.5: Long-term arrivals from Sri Lanka to Australia, 1959-60 to 2012-13

Source: Department of Immigration and Multicultural and Indigenous Affairs, Australian Immigration: Consolidated Statistics, various issues; DIBP, unpublished data.

Jayasuriya and McAuliffe (2013, p. 9) point out that a degree from an Organisation for Economic Co-operation and Development (OECD) university is highly valued in Sri Lanka, and show that Australia is the

2 Persons entering Australia on a temporary residence visa intending to leave but only after spending more than one year in Australia. 
destination for the largest number of student migrants leaving Sri Lanka. Australia has been an important destination for students since the Colombo Plan in the 1960s. There has been a significant increase in the number of student visa holders from Sri Lanka in Australia, from 1,201 in 2002 to 7,555 in 2009. Australia is the destination of over a third of Sri Lankan students going overseas, but Sri Lanka is only the 13th largest supplier of overseas students to Australia.

Temporary skilled migrant workers (subclass 457 visa holders) are also an increasingly important part of the migration flow from Sri Lanka to Australia. The 457 program is entirely demand driven, while the number of permanent immigrants is capped by government. The 457 program is available only to highly skilled workers. Sri Lanka is the fifth largest Asian source of 457 migrants to Australia. As is the case with students, many 457s from Sri Lanka apply for, and are granted, permanent residence in Australia. Temporary migration, like permanent migration, from Sri Lanka to Australia is selective of the highly skilled.

An important dimension of change in Australian international migration over the last 15 years has been the increasing proportion of permanent settlers each year who are persons already in Australia who entered earlier under some form of temporary residence visa. Over a quarter (27.8 per cent) of the 52,791 Sri Lankans who settled permanently in Australia over this period were already in Australia as a temporary resident before applying successfully for permanent residence. There is, therefore, a pattern of Sri Lankans travelling to Australia as a student or skilled temporary worker and, upon completion of their studies or work contract, taking up permanent residence. This has become a common pattern among students in Australia from Asia. In 2011-12, some 30,978 former students applied for, and obtained, permanent residence in Australia.

Moreover, it is apparent that different waves of migrants from Sri Lanka to Australia have been dominated by different ethnic groups. In the late nineteenth century it was mainly Sinhalese. In the early post-World War II decades it was mainly Burghers, and in the latest wave (after the mid-1980s) it was Tamils.

Table 8.4 shows that the Australian Tamil population is predominantly from Sri Lanka. and that it has doubled in the 2006-11 intercensal period. 
Table 8.4: Persons in Australia indicating their ancestry was Tamil by birthplace, 2006 and 2011

\begin{tabular}{|l|r|r|r|r|r|}
\hline \multirow{2}{*}{ Birthplace } & \multicolumn{7}{|c|}{ Tamil } \\
\cline { 2 - 5 } & \multicolumn{2}{|c|}{2006} & \multicolumn{2}{c|}{2011} & \multirow{2}{*}{$\%$ change } \\
\cline { 2 - 6 } & \multicolumn{1}{|c|}{ No. } & \multicolumn{1}{c|}{$\%$} & \multicolumn{1}{c|}{ No. } & \multicolumn{1}{c|}{$\%$} \\
\hline Sri Lanka & 5,158 & 64.1 & 11,630 & 63.7 & 125.9 \\
\hline Australia & 1,312 & 16.3 & 2,811 & 15.4 & 114.3 \\
\hline Malaysia and Singapore & 515 & 6.4 & 1,014 & 5.6 & 96.9 \\
\hline India & 505 & 6.3 & 1,293 & 7.1 & 156.0 \\
\hline Other & 558 & 6.9 & 1,503 & 8.2 & 169.4 \\
\hline Total & 8,048 & 100.0 & 18,251 & 100.0 & 126.8 \\
\hline
\end{tabular}

Source: Data derived from Australian censuses, 1901 to 2011.

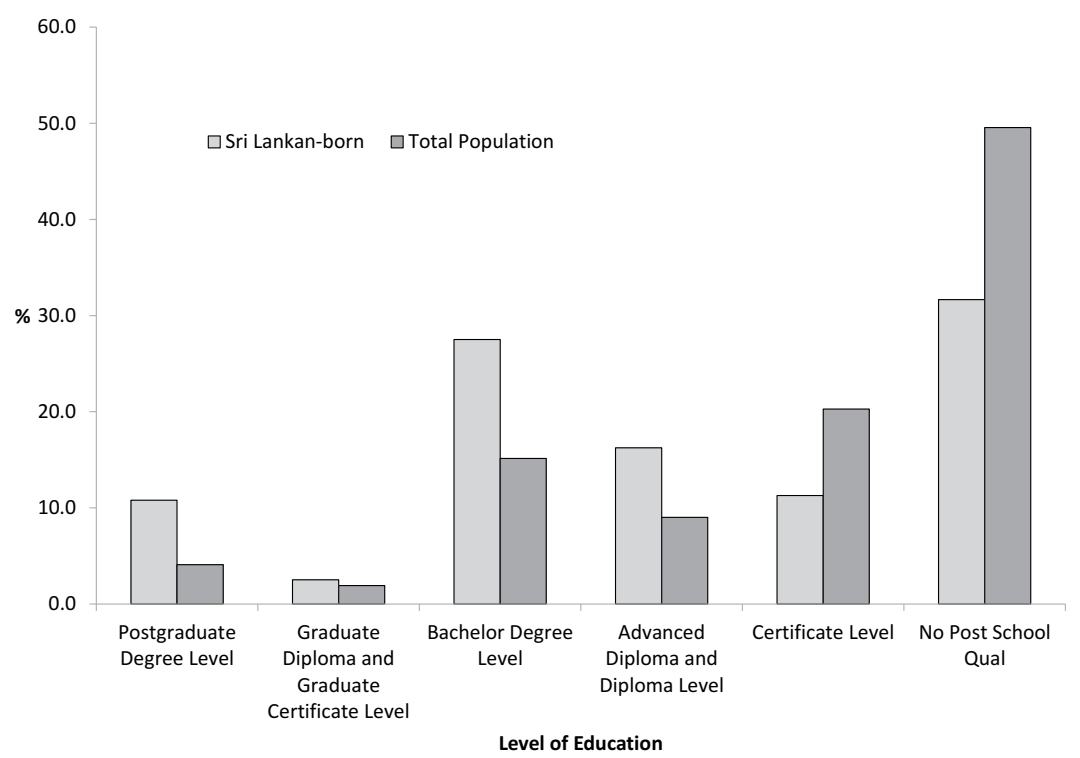

Figure 8.6: Level of post-school qualification of total Australian and Sri Lankan-born population, 2011

Source: Data derived from Australian censuses, 1901 to 2011.

Policy-imposed selectivity is evident when we examine the educational qualifications of the Australian Sri Lankan-born population. Figure 8.6 shows that 30.6 per cent of the Sri Lankan-born population aged 15 years and over in Australia did not have a post-school qualification compared with 52.5 per cent of the total Australian population. However, the difference is most dramatic for those with a University degree or higher qualification, since more than 30 per cent of the Sri Lankan-born are 
at this level compared with 15 per cent of the total Australian adult population. For higher degrees it is 10.8 compared with 4.1 per cent. This points to a very high level of educational selectivity in the permanent migration from Sri Lanka to Australia.

Thus far, our focus has been on the flows of Sri Lankans moving to Australia as well as the characteristics of the Sri Lankan population in Australia. It is also important to appreciate that there are reciprocal and circular flows between Australia and Sri Lanka. Indeed, it has been argued that it is more appropriate to view Asian-Australian migration as a complex interactive system rather than a unidirectional permanent relocation of populations (Hugo, 2008a, 2008b). This certainly applies to the migration relationship between Australia and Sri Lanka. It is important to establish the extent and nature of these reciprocal movements, since they can influence development in Sri Lanka.

The flow from Australia to Sri Lanka, like the permanent flow in the other direction, is highly skilled. Revealingly, managers and professionals make up 65 per cent of all departures. It is clear that in the flow from Australia to Sri Lanka, the dominant group are those in the economically active age groups and their children. Hence, their potential to have a positive impact on development in Sri Lanka is considerable.

Permanent return migration is not the only form of movement that Sri Lankan expatriates in Australia have with their homeland. In fact, Sri Lankans overseas can keep a significant investment in their homeland by frequently visiting and maintaining economic links with institutions and individuals in Sri Lanka. Table 8.5 identifies three types of Sri Lankanborn individuals who indicated they are moving in and out of Australia on a temporary (either long-term or short-term) basis. This table shows three categories of Sri Lankan-born persons according to their residential status and time periods: new settlers 1998-2006; visitors 1998-2006; and Australian residents who settled prior to 1998.

Table 8.5: Number of Sri Lankan-born individual persons travelling in and out of Australia temporarily by resident status, 1998-2006

\begin{tabular}{|l|r|r|}
\hline Sri Lankan-born persons' resident status & $\begin{array}{c}\text { Number moves } \\
\text { into Australia }\end{array}$ & $\begin{array}{c}\text { Travelling out } \\
\text { of Australia }\end{array}$ \\
\hline New settlers 1998-2006 & 13,279 & 272 \\
\hline Visitors 1998-2006 & 22,355 & 15,814 \\
\hline Australian residents who settled prior to 1998 & 24,021 & 24,320 \\
\hline
\end{tabular}

Source: DIBP, unpublished data. 
What is apparent, then, is that many Sri Lankan-born people settling in Australia have made several temporary moves out of Australia since arriving.

\section{Refugee migration}

Since the mid-1980s Sri Lanka has been a significant source of both asylum seekers and refugees as is shown in Figure 8.7.

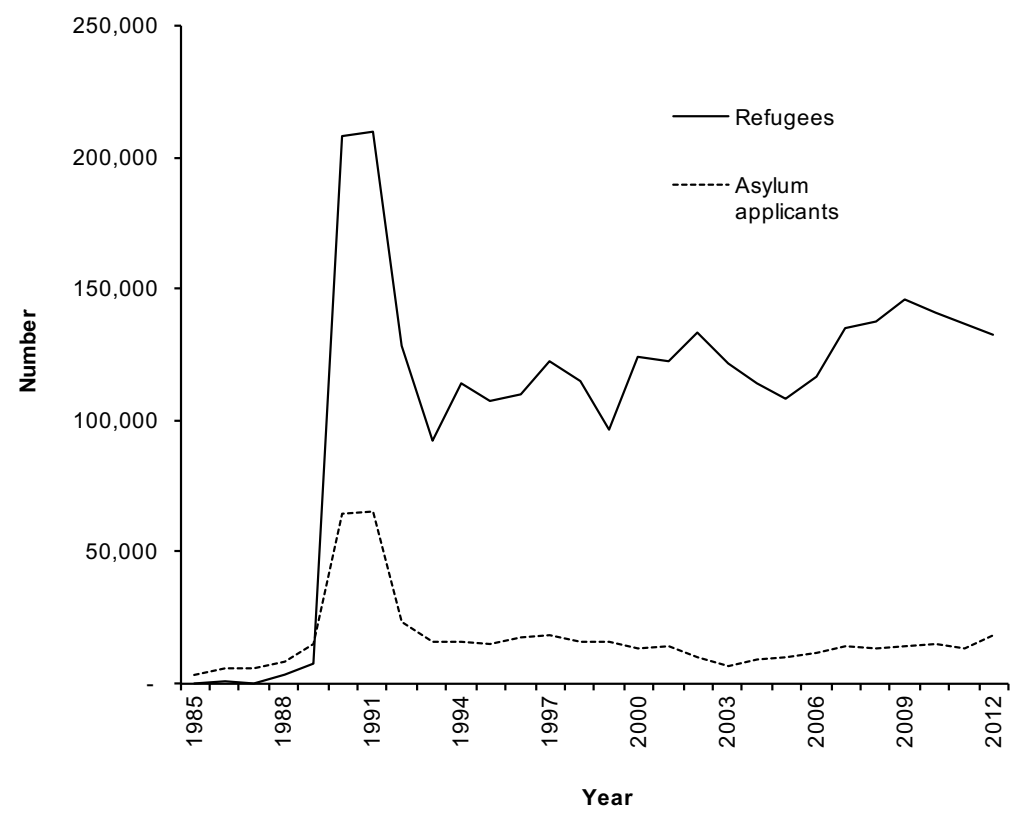

Figure 8.7: Refugees and asylum applicants from Sri Lanka, 1985-2012 Source: UNHCR Statistics.

Most have been Tamils who have been displaced as a result of the civil conflict. As Jayasuriya and McAuliffe (2013, p. 15) point out:

India has historically been, and continues to be, the main host country of Sri Lankan refugees. At the end of 2012 it hosted some 67,165 Sri Lankan (predominantly Tamil) refugees.... However, estimates of the number of Sri Lankans with pending asylum claims in Tamil Nadu vary considerably between organisations, from around 100,000 to 200,000. 
While India has been the main destination, Sri Lankans have also applied for asylum in a number of OECD and Asian countries. A recent United Nations Office on Drugs and Crime (UNODC) study (2013, p. 28) has shown that in the 1980s, 1990s and early 2000s, the main destinations were Germany, France, UK, Canada and Switzerland.

Figure 8.8 demonstrates that in recent years there have been some significant changes, with the largest numbers now being in France, and Malaysia and Australia becoming increasingly significant. Table 8.6 reveals that France and Australia have received the largest number of asylum applications up to the first half of 2013, with Australia experiencing a sharp increase in 2012.

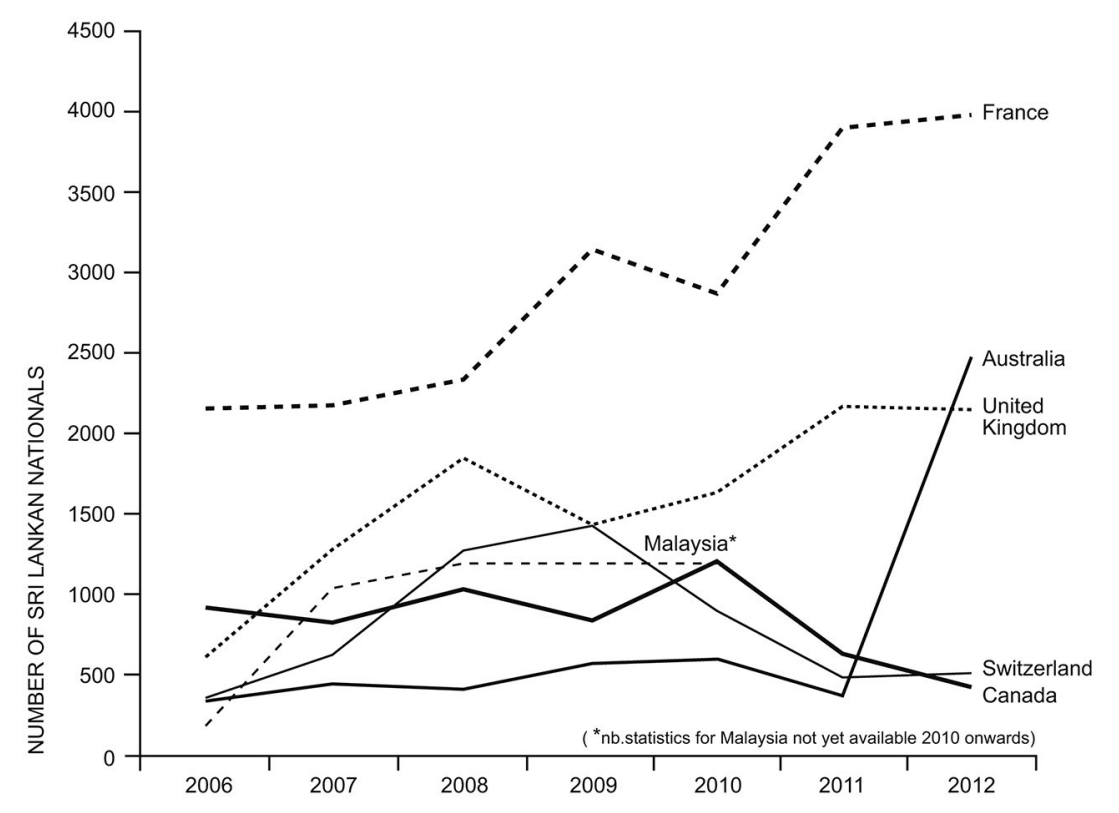

Figure 8.8: Asylum claims, Sri Lankan nationals, six most important countries, 2006-12

Source: UNODC (2013, p. 29). 
Table 8.6: Sri Lankan global asylum applications, 2012 and 2014

\begin{tabular}{|l|r|r|}
\hline Country & 2012 & 2014 \\
\hline France & 6,890 & 3,700 \\
\hline Australia & 2,427 & 1,194 \\
\hline UK & 3,162 & 2,645 \\
\hline Malaysia & 709 & 1,752 \\
\hline Switzerland & 1,177 & 1,277 \\
\hline Germany & 481 & 534 \\
\hline Indonesia & 360 & 238 \\
\hline Canada & 428 & 196 \\
\hline Japan & 461 & 755 \\
\hline
\end{tabular}

Source: United Nations High Commissioner for Refugees (UNHCR) population statistics, extracted 13 January, 2014.

Note: UNHCR data does not include all IMAs to Australia, only those who were able to lodge an asylum claim following the lifting of a statutory bar.

There are more than 100,000 ethnic Tamil Sri Lankans in the southern Indian state of Tamil Nadu, including 68,000 in 112 government-run camps and 32,000 outside camps (IRIN, 2012). It is important to note that India, which has been the host for the majority of war refugees, shows a clear downward trend in the numbers of Tamil Sri Lankans because, as has been reported, an increasing number of refugees are returning home, both spontaneously and with the help of the UNHCR (Refugees return by ferry, 2011).

\section{The migration industry in Sri Lanka}

Overseas migration became an industry with the opening up of the Sri Lankan economy during the late 1970s. Prior to that, migrating overseas was an individual affair and there was little third-party involvement in Sri Lanka. Overseas migration was mainly for higher education and employment. As Sri Lanka began to encourage labour migration to Middle Eastern countries, a 'migration industry' was built. It initially started with a few unauthorised migration agents in Colombo. It expanded to include both authorised and unauthorised agents not only for sending unskilled and semi-skilled labour migrants overseas but also for skilled migration to immigration-encouraging countries such as Australia, New Zealand and Canada. 
The government created a Foreign Employment Unit in the Department of Labour in 1976 in order to find employment overseas, organise and monitor migration as well as maintain migration records (Korale, 1983). In 1980, the Foreign Employment Act No. 32 allowed private agencies to take care of some of the governmental functions and responsibilities of managing overseas labour employment but with governmental control (Gamburd, 2000). Figure 8.9 shows that the number of licensed agencies has grown significantly over the years.

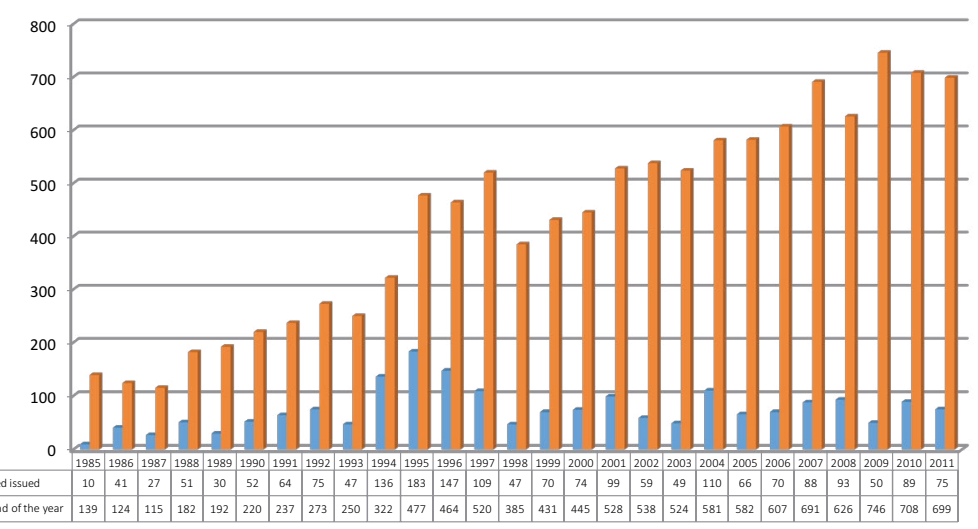

Figure 8.9: Number of licensed agencies, 1985-2011

Source: Sri Lanka Bureau of Foreign Employment (2011).

Note: Blue bars show the new licences issued each year for the newly established agencies.

A substantial institutional framework has developed in Sri Lanka to govern labour migration. The Sri Lankan Foreign Employment Agency Ltd was set up in 1996 for directing youth into foreign employment. This agency functions under the Ministry of External Affairs and manages the recruitment for employment overseas.

Departures for foreign employment have grown between 2006 and 2011 in almost all the districts, but the volume of departures is relatively low for the northern districts of Sri Lanka, as depicted in Figure 8.10. Potential migrants did not have the opportunity to leave the northern districts during the war period in order to be involved in the process of labour migration since almost all of the licensed agencies are located outside the Northern Province, and mainly in Colombo and Kurunegala districts.

Although a coherent framework for governing labour migration is in place in Sri Lanka, a substantial proportion of migrants prefer to take up informal channels to organise their migration (Eelens, 1995; Gamburd, 
2000, 2005; Gunatilleke, 1998; Shaw, 2008; Ukwatte, 2010). Shaw $(2008)^{3}$ observed that about one third of migrants organised their migration through informal contacts.

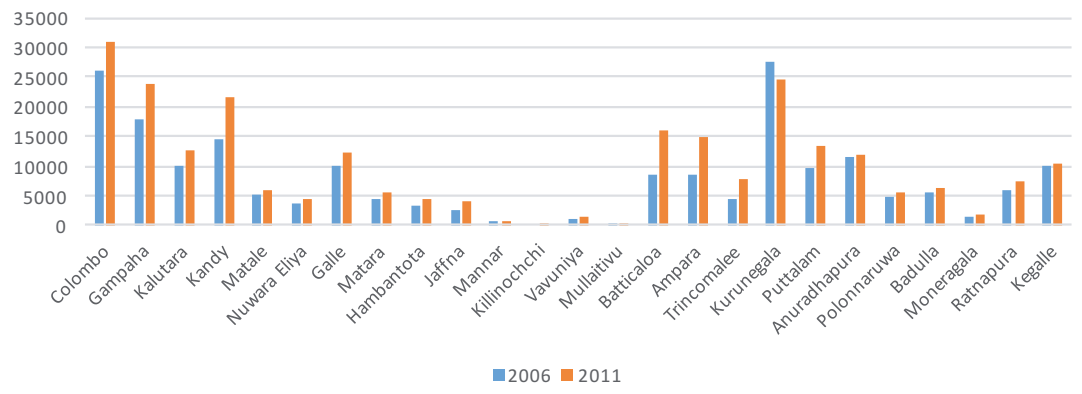

Figure 8.10: Departure for foreign employment by district, 2006 and 2011 Source: Sri Lanka Bureau of Foreign Employment, various reports.

The Sri Lanka Bureau of Foreign Employment reports that only 75.5 per cent of the departures in 2008 were from licensed agencies (Sri Lanka Bureau of Foreign Employment, 2009, p. 5). Many studies have reported that numerous illegal recruitments continue, ${ }^{4}$ although the number of licensed agencies has increased (Dias \& Jayasundera, 2004; Eelens \& Speckmann, 1990).

Boat migration or IMAs is not a phenomenon that has been specifically developed for Australia. The smuggling of people overseas from Sri Lanka by boat was booming a decade ago (Brown, 2012). Although Australia became the preferred destination of smuggled migrants in 2012-13, Italy has in the past been one of the major destinations. IMAs to Italy changed significantly in 2002 for two reasons. First, the Italian Parliament sanctioned a new immigration law known as the Bossi-Fini law that allowed for regularisation of those already living in Italy, as well as devising a mechanism for the processing of new immigrants with offices all over the country and severe border controls (Totah, 2003). The second was a consequence of the Asia-Europe Meeting (ASEM) Ministerial Conference on Cooperation for the Management of Migratory Flows between Europe and Asia, which paved the way for the Italian

3 Shaw's paper is based on fieldwork conducted in 2006 in Kurunegala district, a rural agrarian region about 70 kilometres northeast of Colombo. A mix of quantitative and qualitative techniques has been employed. The primary survey instrument was a structured questionnaire, administered to individuals responsible for household finances in 153 remittance-receiving households in which the migrant had been abroad for six months or more at the time of the survey.

4 'Illegal recruitments' means the recruitment of labour by nonlicensed recruiters. 
Government to establish bilateral agreements with sending countries to help curb illegal migratory flows by offering them special quotas for immigrants and readmission priorities in exchange for their cooperation. Most importantly, the agreement supported externalising the policing of the Italian border by cooperating logistically and financially with local law enforcement agencies to stop IMAs at the point of departure.

International migration has increased significantly in Asia during the past two decades (Hugo \& Young, 2008). Although there have been some initiatives to improve governance and cooperation in relation to international migration, undocumented movement remains a major challenge (Abella, 2008; Colford, 2013). The International Organization for Migration (2010) has estimated that there are 20 to 30 million migrants worldwide without proper documentation.

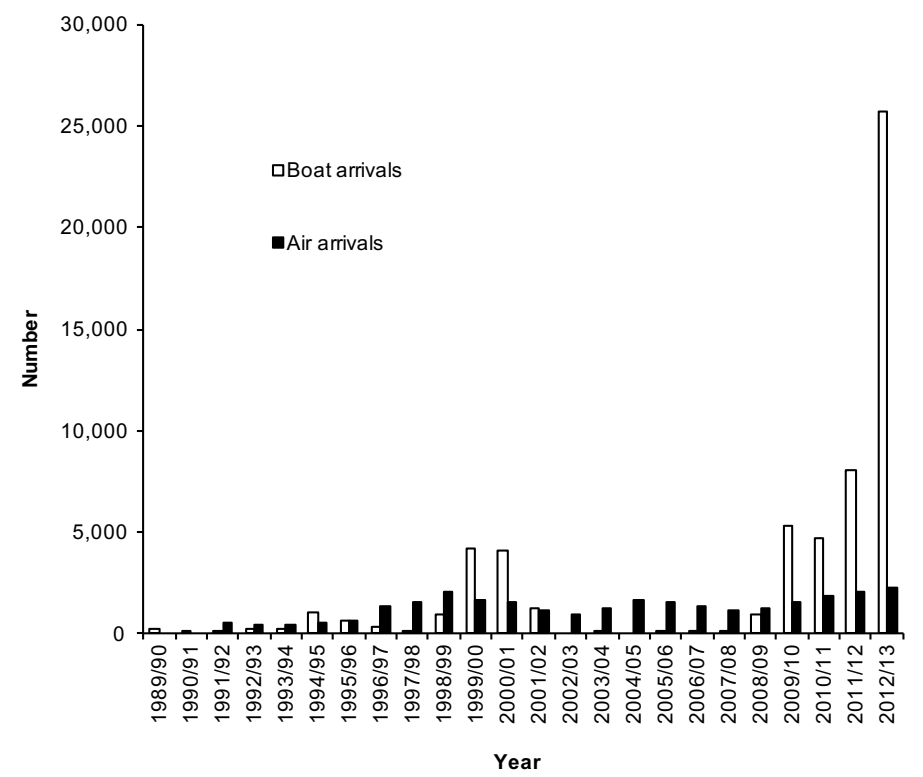

Figure 8.11: Unauthorised arrivals to Australia, $1989-90$ to 2012-13

Source: Department of Immigration and Multicultural and Indigenous Affairs (2002, 2004, 2005); Department of Immigration and Citizenship, Annual Report, various issues; Phillips and Spinks (2013).

Persons who arrive in Australia without a visa, most of whom ultimately apply for asylum, arrive by sea and air, and the numbers are shown in Figure 8.11. Sri Lankans were an important part of this upswing in IMAs. In 2008 there were just over 200 IMAs from Sri Lanka, but in 2012 there were over 6,400 . 
Jayasuriya and McAuliffe (2013, p. 19) note that there has been an increase in the number of asylum seekers repatriated to Sri Lanka: between July 2012 and May 2013, 162 voluntary and 965 involuntary returns were undertaken. At the Sri Lanka end, data obtained from the Katunayake Airport shows nonvoluntary returnees by special charter flights in 2012-13 were 1,265 compared with 56 voluntary returnees by commercial flights, as depicted in Figure 8.12. All the voluntary returnees were males, while 6.2 per cent of the nonvoluntary migrants were females.

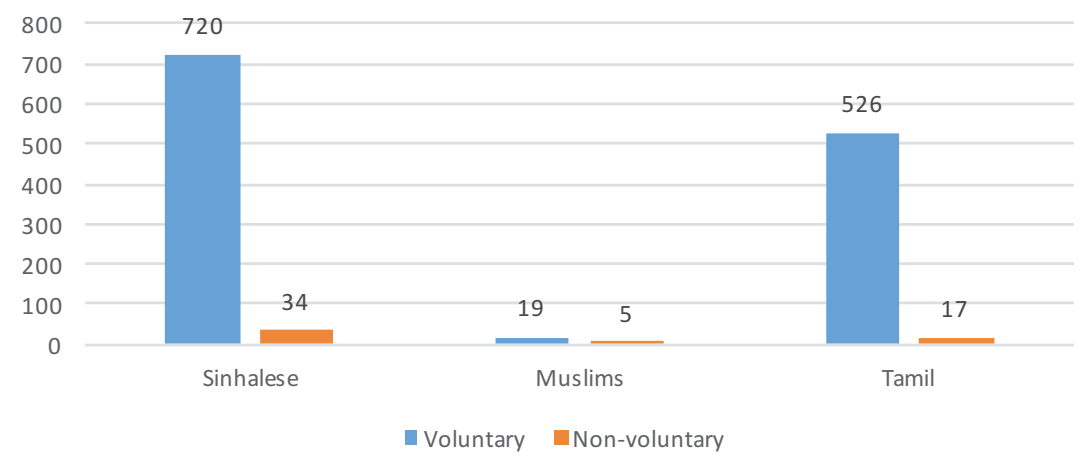

Figure 8.12: Number of voluntary and nonvoluntary returnees from Australia, 2012-13

Source: Data obtained from various annual reports - Bandaranaike Airport. Retrieved from www.airport.Ik/aasl/business_info/annual_reports.php.

In recent years, it was not only Tamils who were involved with boat migration, but Sinhalese as well. There were no Sinhalese IMAs in 2011 but their number suddenly jumped to 13 per cent in 2012 (Jayasuriya $\&$ McAuliffe, 2013). This suggests that the reasons for boat migration are not related only to factors linked with 'protection'. Table 8.7 shows that interdictions were on a substantial scale. Moreover, they were at a high level at the time of peak IMA arrivals from Sri Lanka in Australia.

Table 8.7: Sri Lankan irregular migrants detected by the Sri Lankan authorities, 2009-12

\begin{tabular}{|l|r|r|r|r|r|}
\hline Item & 2009 & 2010 & 2011 & 2012 & Total \\
\hline Total number of vessels detected & 8 & 3 & 3 & 67 & 81 \\
\hline Total number of passengers arrested & 182 & 10 & 115 & 3,139 & 3,446 \\
\hline Total number of facilitators arrested & 35 & 19 & 12 & 304 & 370 \\
\hline
\end{tabular}

Source: Criminal Investigation Department, Sri Lanka. Data collected by the authors. 
Most of the IMAs originated from the Northern and Eastern provinces, which were conflict-affected districts for more than two decades. In 2012, the Eastern districts of Trincomalee and Batticalo and the Northern district of Vavuniya dominated the irregular maritime migration, but a completely different pattern of migration was observed for 2013, as shown in Figure 8.13.

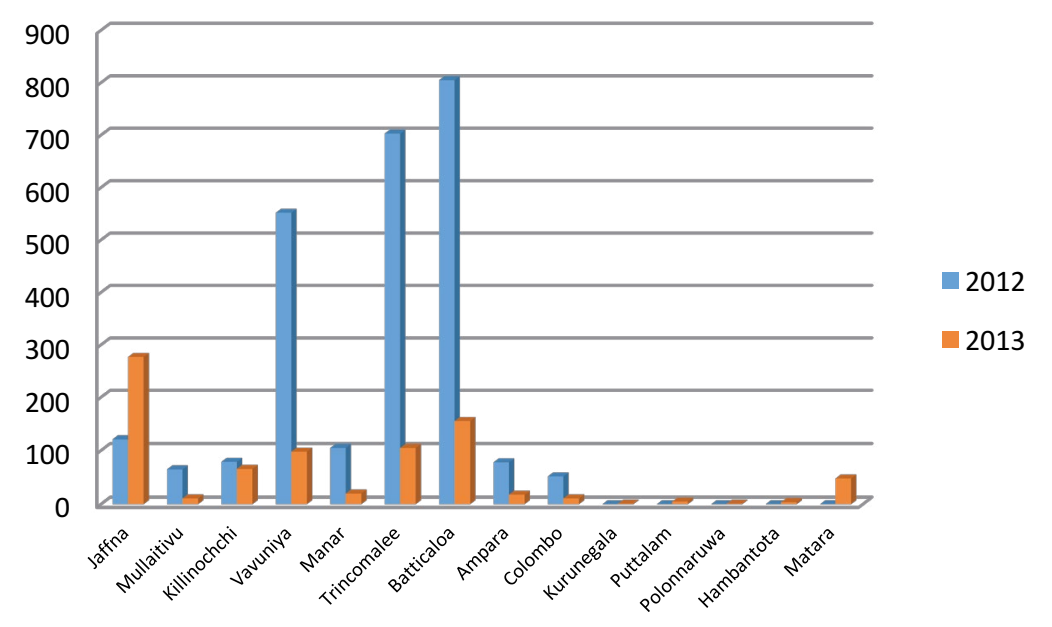

Figure 8.13: District of origin of irregular maritime migrants, 2012 and 2013 Source: Criminal Investigation Department, Sri Lanka. Data collected by the authors.

The Northern district of Jaffna has produced many irregular maritime migrants, while other districts both in the Northern as well as Eastern provinces have a smaller number of migrants. The most important feature of the differences between 2012 and 2013 was the substantial decline of irregular maritime migration in all the districts except Jaffna.

Figure 8.14 shows that of those who attempted to depart for Australia by boat between January 2012 and October 2013, the majority were Tamil. These people were arrested while attempting to depart or before crossing the Sri Lankan sea border. If 'protection factors' are the reason for illegal maritime migration, as indicated by some authors (Howie, 2013; Kanagasabapathipillai, 2013), involvement of a large number Sinhalese and a significant number of Muslim migrants raises questions as to what the reasons are behind their migration. Many who have investigated 'boat migration' suggest that an economic motive was also a main reason (Waduge, 2013; Karunaratne, 2013; Kariyakarawana, 2013; Saravanathan, 2013). 


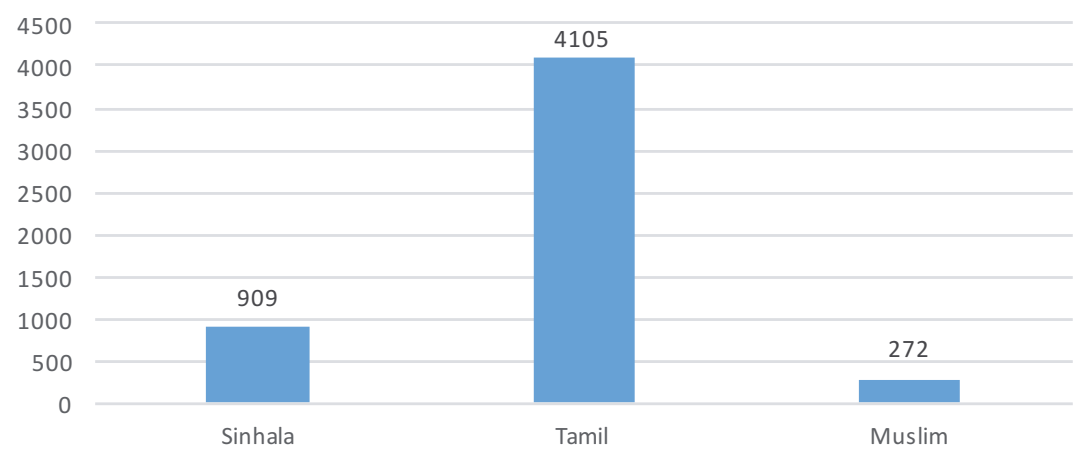

Figure 8.14: Number of people captured while departing to Australia by ethnicity, January 2012 to October 2013

Source: Criminal Investigation Department, Sri Lanka. Data collected by the authors.

It is interesting to note that all ventures in 2013 involved children, compared with less than half (22) of the 56 attempts in 2012 . The majority of the latter occurred towards the end of 2012.

Irregular maritime migrants interviewed were either unemployed or worked in low-paid, informal-sector occupations. They worked as fishermen, drivers, farmers or labourers. Most of the illegal migrants were the eldest child of their family, who took on the responsibility of supporting the family including younger siblings who are still schooling. The majority of them do not own any property, and others only owned their house. Therefore, the migrants generally come from very poor families.

The Sri Lankan community in Australia plays a significant role in the migration of Sri Lankans to Australia-both documented and undocumented. This role involves the supply of information, both detailed and general, in terms of the economic and social opportunities in Australia. The community also helps to fund migration, and in some cases community members act as sponsors.

There appears to be some mismatch between the fact that most of the IMAs detected either in Sri Lanka or Australia tend to have middle to low education and low status occupations while the Sri Lankan population in Australia tends to have higher levels of education and occupational status.

The role of family in Australia and in other countries in influencing the decision to migrate was evident in the comments from a repatriated respondent. A 27-year-old Tamil man from Trincomalee explained to us that: 
I am still unemployed because I have studied up to GCE (O. L.) but was not successful. My family still supports me because my brother is in England and the sister live in Canada. I can communicate in English to some extent. I also have some relatives living in Australia. I am very much frustrated because only I have this low standard of living in Sri Lanka. For this reasons I decided to migrate to Australia by boat because one of my friends who went to Australia by boat suggested me that it saves time and money. Although the bad memories of war are over, there are many jobless youth so I was expecting better opportunities in Australia.

The intending IMAs that were intercepted by the Anti-Human Smuggling Unit of Sri Lanka's Criminal Investigation Department were overwhelmingly young, and the majority came from the Northern and Eastern regions, so they are Tamils. They have a strong network in Australia because of the relatives and friends who live there and receive encouragement to travel to Australia by illegal means to avoid the immigration screening.

The study of IMAs who have been successful in gaining protection (McAuliffe, 2013) showed in the case of Sri Lankans that more than 15 per cent had relatives, more than 10 per cent had friends, friends of relatives or friends of friends, and a little less than 5 per cent had fellow ethnic members in Australia prior to their departure.

Regional disparities in development in Sri Lanka have led people to migrate locally or internationally looking for better income opportunities. The government is now making a significant attempt to develop war-torn Northern and Eastern districts. It is important to stress that Sri Lankan people have become very mobile locally as well as internationally. The major reason for such movement is to find better employment, whether locally or overseas. Moreover, illegal migration to overseas countries to look for employment opportunities is not a new phenomenon. Sri Lanka already had a network of agents able to organise this illegal movement. In addition, we have seen a mass flow of refugees to India, by boat, during the war years. Therefore, 'boat' migration to overseas destinations involving risks is not a recent phenomenon for the low socioeconomic portion of the Sri Lankan community, irrespective of their ethnicity. Moreover, the idea that migration-especially international migrationis the key to prosperity has become a norm in Sri Lanka. 


\section{Conclusion}

Sri Lanka has become, in many ways, a major emigrant society over recent decades. There are a number of elements to this. First, the country has a substantial diaspora. In 2013 the United Nations indicated there were $1,245,187$ Sri Lankan-born persons living in other countries, equivalent to 5.9 per cent of the Sri Lankan resident population. Second, remittances now account for 10.1 per cent of GDP (World Bank, 2014). Third, a strong local culture of migration has developed, whereby internal and international migration is seen as a normal way for Sri Lankans to seek to improve their economic situation or respond to crisis.

Sri Lanka has initiated several livelihood development programs under its policy known as Mahinda Chinthanaya. ${ }^{5}$ But these programs need to be accelerated and better accommodate the most vulnerable and disadvantaged communities, especially in the northern and eastern parts of the country, where the majority of the IMAs originated. This study has found that most of the IMAs are less-educated and low-skilled people from these areas. It is important to enhance their vocational skills according to the jobs demanded by the labour market in Sri Lanka without making a mismatch between education or skills with the available employment opportunities. In this regard, preparing a livelihood development plan specifically designed for the Northern Province-by identifying, with the participation of local communities, the livelihood requirements of individuals as well as communities-seems beneficial.

One of the few generalisations which has emerged from research on irregular and undocumented migration is that it often occurs because there are no regular or documented channels available for potential migrants, so that they are left with no alternative but to move irregularly. It follows that the most successful measures to prevent irregular migration involve the creation of legal channels that make irregular migration unnecessary. Usually, this is considered in terms of creating those channels along

5 Mahinda Chinthanaya, which is the Sri Lankan Government's policy agenda, strongly emphasises that public spending should be pro-poor, pro-growth and pro-regional. In this context, rural-urban imbalances in access to transport, electricity, quality drinking water, education and health are being attended with more resources being allocated to supplement regular programs through regionally focused development initiatives: Uthuru Wasanthaya, Negenahira Navodaya, Rajarata Navodaya, Wayamba Pubuduwa, Pubudamu Wellassa, Kandurata Udanaya, Sabaragamu Arunalokaya and Ran Aruna. Furthermore, public investment is expected to promote growth and value-creation opportunities. In addition, spending on social security will be encouraged through community participation. 
the same corridors of what is currently irregular migration. However, a somewhat different initiative is suggested here, noting that the major areas of origin of IMAs who have attempted to move to Australia have a number of key characteristics:

- Low levels of education and skill, so that few people are eligible for skilled migration, permanent or temporary, to OECD nations.

- No readily available channels for contract labour migration to the Middle East and Southeast Asia, because of a lack of agents and an insecure situation which has prevented recruiters and other parts of the migration industry to operate in those parts of the country.

Accordingly, it is suggested that steps be taken by the Sri Lankan Government to create legal alternatives to IMA migration to Australia by setting up the full infrastructure to recruit, process etc. international labour migrants in the region for the Middle East and Southeast Asia. This would also involve providing training facilitators for local people, to fit the needs of employers in the Middle East and Southeast Asia.

A major policy implication of this report is that, rather than try to prevent migration from the 'hot spots' from which IMAs have left, we seek to facilitate legal migration through regular channels to the Middle East and Southeast Asia. This builds on the considerable infrastructure and experience that already exists in other parts of Sri Lanka. It builds on the culture of migration in the area, but channels it into other more secure pathways to legal movement overseas.

\section{Reference list}

Abella, M. I. (2008, 25-28 March). Challenges to governance of labour migration in Asia-Pacific. Paper presented at PECC-ABAC conference on demographic change and international labour mobility in the Asia-Pacific Region: Implications for business and cooperation, Seoul, Korea.

Australian Bureau of Statistics. (2013). Migration Australia-2011-12 and 2012-13. Catalogue No. 3412.0. Canberra: Author.

Brown, B. (2012). Undocumented Sri Lankan migration to Italy: Its rise and fall. Retrieved from groundviews.org/2012/08/02/the-rise-andfall-of-sri-lankan-undocumented-migration-to-italy/. 
Colford, P. (2013, 2 April). 'Illegal immigrant' no more. Retrieved from Associated Press: blog.ap.org/2013/04/02/illegal-immigrant-no-more.

Cornelius, W. A. (1992). From sojourners to settlers: The changing profile of Mexican immigration to the United States. In Bustamante, J. A., Reynolds, C. W. and Hinojosa-Ojeda, R. (Eds), US-Mexico relations: Labor market interdependence. Stanford: Stanford University Press.

del Rey Poveda, A. (2007). Determinants and consequences of internal and international migration: the case of rural populations in the south of Veracruz, Mexico. Demographic Research, 16(10): 287-314.

Department of Immigration and Border Protection (DIBP). Overseas arrivals and departures statistics, unpublished data.

Department of Immigration and Citizenship. Annual report, various issues. Canberra: Australian Government Publishing Services.

Department of Immigration and Multicultural and Indigenous Affairs. Australian immigration: Consolidated statistics, various issues. Canberra: Australian Government Publishing Services.

Department of Immigration and Multicultural and Indigenous Affairs. (2002). Unauthorised arrivals by air and sea. Fact sheet 74. Canberra: Australian Government Publishing Services.

Department of Immigration and Multicultural and Indigenous Affairs. (2004). Unauthorised arrivals by air and sea. Fact sheet 74. Canberra: Author.

Department of Immigration and Multicultural and Indigenous Affairs. (2005). Managing the border: Immigration compliance 2004-05 edition. Canberra: Australian Government Publishing Services.

Dias, M., \& Jayasundara, R. (2004). Sri Lanka: Good practices to prevent women migrant workers from going into exploitative forms of labour. GENPROM working paper No. 9. Series on Women and Migration. Geneva: Gender Promotion Program, International Labour Organization. 
Eelens, F. (1995). Migration of Sri Lankan women to Western Asia. In International migration policies and the status of female migrants: Proceedings of the United Nations Expert Group meeting on international migration policies and the status of female migrants, San Miniato, Italy, 28-31 March 1990, Issue 126 (pp. 267-77). Geneva: United Nations.

Eelens, F., \& Speckmann, J. D. (1990). Recruitment of labour migrants for the Middle East: The Sri Lankan case. International Migration Review, 24(2), 297-322. doi.org/10.2307/2546553

Gamburd, M. R. (2000). The kitchen spoon's handle: Transnationalism and Sri Lanka's migrant housemaids. New York: Cornell University Press.

Gamburd, M. R. (2005). Lentils there, lentils here! Sri Lankan domestic labour in the Middle East. In Huang, S., Yeoh, B. S. A., \& Rahman, N. A. (Eds), Asian Women as Transnational Domestic Workers, (pp. 92114). Singapore: Marshall Cavendish Academic.

Gunatilleke, G. (1998). The role of networks and community structures in international migration from Sri Lanka. In Appleyard, R. (Ed.), Emigration dynamics in developing countries. Volume II: South Asia (pp. 71-112). Surrey: Ashgate.

Howie, E. (2013). Sri Lankan boat migration to Australia: Motivations and dilemmas. Economic and Political Weekly, 48(35), 97-104.

Hugo, G. J. (1999). A new paradigm of international migration in Australia. New Zealand Population Review, 25(1-2), 1-39.

Hugo, G. J. (2008a). In and out of Australia: Rethinking Indian and Chinese skilled migration to Australia. Asian Population Studies 4(3), 267-91. doi.org/10.1080/17441730802496508

Hugo, G. J. (2008b). Quantifying transnationalism: Asian migration to Australia. In Stojanov, R., \& Novosak, J. (Eds), Migration, development and environment: Migration processes from the perspective of environmental change and development approach at the beginning of the 21st Century (pp. 172-208). Newcastle: Cambridge Scholars Publishing.

Hugo, G. J. (2014). Sri Lankan migration to Australia. Sri Lanka Journal of Population Studies 14, 1-32. 
Hugo, G. J. (2015). The Sri Lankan population in Australia. In Dissanayake, L., \& Ukwatta, S. (Eds), Population and development (pp. 15-38). Colombo: Department of Demography, University of Colombo.

Hugo, G., \& Young, S. (Eds). (2008). Labour mobility in the Asia-Pacific region. Singapore: Institute of Southeast Asian Studies.

IRIN. (2012, 4 September). Refugees in India reluctant to return. Retrieved from www.irinnews.org/report/96233/sri-lanka-refugeesin-india-reluctant-to-return.

International Organization for Migration. (2010). World migration report 2010: The future of migration - Building capacities for change. Geneva: Author.

Jayasuriya, D., \& McAuliffe, M. (2013). Placing recent Sri Lankan maritime arrivals in a broader migration context. Irregular Migration Research Program Occasional Paper Series 02. Canberra: Department of Immigration and Border Protection.

Kanagasabapathipillai, D. (2013, 22 August). The Illegal Boat Ride to Australia. Ceylon Today. Retrieved from passionparade.blogspot.com/ 2013/08/.

Kariyakarawana, K. (2013, 1 September). Sri Lanka-Australia to check illegal migrants. Sunday Observer. Retrieved from archives.sunday observer.lk/2013/09/01/sec03.asp.

Karunaratne, C. (2013, 18 December). Sri Lankans and irregular migration: A journey to die for? Daily Mirror. Retrieved from www.dailymirror.lk/ business/features/40380-sri-lankans-and-irregular-migration-a-journeyto-die-for.html.

Khoo, S., McDonald, P., \& Hugo, G. J. (2009). Skilled temporary migration from Asia-Pacific countries to Australia. Asian and Pacific Migration Journal, 18(2), 255-81. doi.org/10.1177/011719680901800204

King, R. (1976). The evolution of international labour migration movements concerning the EEC. Tijdschrift voor Economische en Sociale Geografie, 67(2), 66-82. 
King, R., Skeldon, R., \& Vullnetari, J. (2008). Internal and international migration: Bridging the theoretical divide. Sussex Centre for Migration Research, University of Sussex, UK. Retrieved from eprints.soton. ac.uk/377323/.

King, R., Skeldon, R., \& Vullnetari, J. (2012). Internal and international migration: Bridging the theoretical divide. Sussex Centre for Migration Research, University of Sussex, UK. Retrieved from www.imi.ox.ac. uk/pdfs/russell-king-ron-skeldon-and-julie-vullnetari-internal-andinternational-migration-bridging-the-theoretical-divide.

Korale, R. B. M. (1983). Migration for employment to the Middle East: Its demographic and socioeconomic effects in Sri Lanka. Colombo: Ministry of Plan Implementation.

Lozano-Ascencio, F., Roberts, B., \& Bean, F. (1999). The interconnections of internal and international migration: The case of the United States and Mexico. In Pries, L. (Ed.), Migration and transnational social spaces, (pp. 138-61). Aldershot: Ashgate.

McAuliffe, M. (2013). Seeking the views of irregular migrants: Decision making, drivers and migration journeys. Irregular Migration Research Program, Occasional Paper Series 05. Canberra: Department of Immigration and Border Protection.

Phillips, J., \& Spinks, H. (2013). Boat arrivals in Australia since 1976. Parliamentary library research paper. Canberra: Parliament of Australia. Retrieved from www.aph.gov.au/About_Parliament/Parliamentary_ Departments/Parliamentary_Library/pubs/rp/rp1314/BoatArrivals.

Refugees return by ferry. (2011, 13 October). Daily FT. Retrieved from www.ft.lk/article/51807/Refugees-return-by-ferry.

Sarvananthan, M. (2013). Causes of 'boat migration' to Australia from Sri Lanka: A rejoinder to Emily Howie. Ground Views for Journalism. Retrieved from groundviews.org/2013/09/08/causes-of-boat-migrationto-australia-from-sri-lanka-a-rejoinder-to-emily-howie/.

Shaw, J. (2008). Sri Lanka country study. In Shaw, J., \& Eversole, R. (Eds), Leveraging remittances with microfinance: Synthesis report and country studies (pp. 153-94). Melbourne: AusAID Research Reports. 
Skeldon, R. (2006). Interlinkages between internal and international migration and development in the Asian region. Population, Space and Place, 12(1), 15-30.

Sri Lanka Bureau of Foreign Employment. (2009). Annual statistical report of foreign employment. Colombo: Author.

Sri Lanka Bureau of Foreign Employment. (2011). Annual statistical report of foreign employment. Colombo: Author.

Totah, M. (2003). Comment-Fortress Italy: Racial politics and the new immigration amendment in Italy. Fordham International Law Journal, 26(5), 1438.

Ukwatte, S. (2010). Economic and social impact of the migration of Sri Lankan transitional domestic workers on families and children left behind (unpublished $\mathrm{PhD}$ thesis). University of Adelaide, Adelaide.

United Nations. (2013). Trends in international migrant stock: The 2013 revision. New York: Author.

United Nations High Commissioner for Refugees. (2003). Sri Lanka. In UNHCR global appeal (pp. 207-11). Geneva: Author. Retrieved from www.unhcr.org/3ddceb71a.pdf.

United Nations Office on Drugs and Crime. (2013). Strategic assessment report on migrant smuggling from Sri Lanka. Report produced by Regional Office for Southeast Asia and the Pacific, United Nations Office on Drugs and Crime.

Waduge, S. D. (2013, 23 July). Point of view boat smuggling mafia Sri Lanka's Tamil 'refugees' or economic migrants? The Island. Retrieved from www.srilankaguardian.org/2013_07_22_archive.html.

Weerasooria, W. S. (1988). Links between Sri Lanka and Australia. Colombo: Government Press.

World Bank. (2014, 11 April). Migration and remittances: Recent developments and outlook. Migration and Development Brief 22. Washington DC: Author.

Zabin, C., \& Hughes, S. (1995). Economic integration and labour flows: stage migration in farm labour markets in Mexico and the United States. International Migration Review, 29(2): 395-422. 
This text is taken from A Long Way to Go: Irregular Migration Patterns, Processes, Drivers and Decision-making, edited by Marie McAuliffe and Khalid Koser, published 2017 by ANU Press, The Australian National University, Canberra, Australia.

dx.doi.org/10.22459/LWG.12.2017.08 